Disk 10, "atwater" 4/1/83, 4/7/83, 4/19/83, MJM

\title{
GUIDEBOOK FOR 1983 FRIENDS OF THE PLEISTOCENE \\ FIELD TRIP TO THE SANPOIL RIVER VALLEY, NORTHEASTERN WASHINGTON
}

by

Brian F. Atwater

U.S. Geological Survey

Open-File Report $83-456$

April, 1983

Mail Stop 75

345 Middlefield Road

Menlo Park, CA 94025

This report is preliminary and has not been reviewed for conformity with U.S. Geological Survey editorial standards and stratigraphic nomenclature. 


\section{Day 1}

Friday, August 26, 1983

JOKULHLAUPS INTO THE SANPOIL ARM OF GLACIAL LAKE COLUMBIA, WASHINGTON

Leader: Brian F. Atwater

U. S. Geological Survey

345 Middlefield Road

Menlo Park, CA 94025

Released separately as U. S. Geological Survey Open-File Report 83- 
CONTENTS

Page

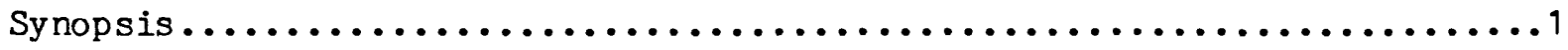

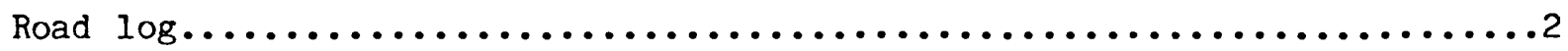

Tables

1. Ranges of varve counts from Fraser-age deposits of the Sanpoil arm...6

2. Varves that can be widely correlated within the lower Sanpoil

River valley..................................

3. Location of principal stratigraphic sections referred to in this

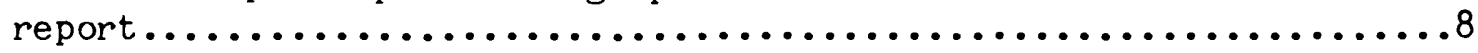

Figures

1. Map showing southern part of the Cordilleran Ice Sheet and adjacent areas during the Fraser glaciation...................

2. Map showing Fraser-age ice margins, shorelines, and paleocurrents

in the vicinity of the lower Sanpoil River valley $\ldots \ldots \ldots \ldots \ldots \ldots . . .10$

3. Longitudinal profile showing glacial, lacustrine, and fluvial

features of the lower Sanpoil River valley..................11

4. Skeletal columnar sections of Fraser-age deposits of the

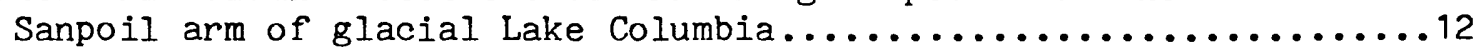

5. Columnar sections showing changes in flood beds beds F-8 and F-9 and in varved bed V-9 along the axis of the Sanpoil River Valley .......13

6. Diagram showing upward progression of grain size and sedimentary structures in flood bed F-8, Old Keller locality .................

7. Diagram showing repeated upward fining of otherwise massive sand in

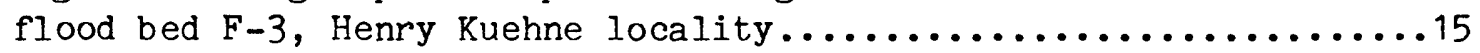

8. Diagram comparing varve counts from Lake Missoula with varve

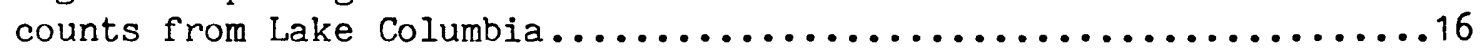

9. Schematic time-stratigraphic correlation of the deposits of Lake Columbia with bottom sediments of Lake Missoula and backflood deposits in

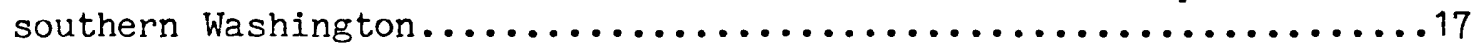

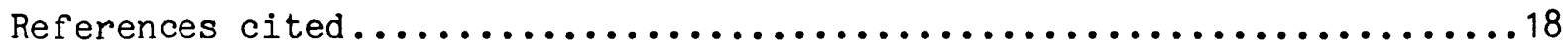




\section{SYNOPSIS}

Tens of last-glacial jokulhlaups from glacial Lake Missoula, Montana, coursed and probably engulfed glacial Lake Columbia, northeastern Washington. In Lake Columbia's Sanpoil arm (figs. 1-3) sets of varves accumulated between beds left by each of at least 40 of the Lake Missoula floods (Fig. 4; stops SA-1, SA-4, SA-5, and SA-6). Sandy parts of the varves display ripple-drift cross lamination (stop $S A-2$ ) and longitudinal thinning (fig. 5; stop $\mathrm{SA}-2$ vs. stop $\mathrm{SA}-3$ ) that require currents directed down the Sanpoil arm (fig. 2); presumably the currents were continuous with outflow from the lobe of the Cordilleran ice sheet that terminated in the Sanpoil arm (fig. 3). The thin basal sand of typical flood beds in the upper part of the Sanpoil arm caused little or no disturbance of underlying varves and grades simply upward into clay (fig. 6; stop SA-2). Farther down the Sanpoil arm, however, the thick basal sand of typical flood beds commonly deformed underlying varves into diapirs and itself became so unstable that it generated turbidity currents whose deposits interrupt the normal grading of the upper parts of flood beds (figs. 5, 7; stops SA-1, SA-3). These features plus ordinary paleocurrent indicators ( $f i g .2$; stop $S A-2$ ) require flow initially directed up the Sanpoil arm. Much of the sand and clay in the flood beds probably came from beyond Lake Columbia because the sand grains are more abundantly lithic and weathered and the clay redder than varved counterparts (stop SA-1). The floods required to introduce this detritus show none of the short-term variability in frequency that is characteristic of meteorological events; rather, the 14 floods whose intervening varves are best exposed recurred once every 35-55 years (stop SA-1; table 1). This regularity implies periodic release of stored water, hence jokulhlaups.

Last-glacial jokulhlaups into glacial Lake Columbia closely resemble last-glacial emptyings of Lake Missoula in frequency and number (fig. 8 and stops SA-4 through -6). Flood beds of the Sanpoil arm are further linked to emptyings of Lake Missoula by alternation of floodlaid beds with sets of about 40 varves at localities closer to Lake Missoula (near Spokane [day 2] and in Priest River Valley [fig. 1]) and by resemblance to rhythmically bedded backflood deposits in south-central Washington. Deposits of the Sanpoil arm thus appear to contain proxies both for the Lake Missoula varves that record each filling of Lake Missoula and for the rhythmites interpreted by Waitt (1980) as recording tens of separate floods from that lake (fig. 9).

A set of exceptionally thin flood beds bracketed by thick flood beds in the Sanpoil arm (F-10 through F-13, fig. 4; stops SA-1 through -3) records absorption of several Lake Missoula jokulhlaups by an exceptionally high (730m) Lake Columbia and (or) partial deflection of these jokulhlaups by a glacial barrier. The thin beds thereby correlate with maximum extension of the Okanogan lobe, which by blocking the Grand Coulee would have raised the lake from $515 \mathrm{~m}$ to about $730 \mathrm{~m}$ (figs. 2, 3), and (or) with maximum extension of the Columbia lobe, which may have partly blocked floods running down Lake Columbia toward the Sanpoil arm (fig. 1). The presence of thick flood beds both above and below the thin flood beds may mean that the bedrock lip of the upper Grand Coulee had already approached its present depth before the last-glacial maximum, perhaps before the last glaciation altogether. 
ROAD LOG

MILEAGE

OBSERVATIONS

Cumul. $\quad$ Between

$0 \quad 0 \quad$ Keller store. Head south on highway 21.

$1.1 \quad 1.1 \quad$ Meadow Creek. A 515-m lacustrine terrace (fig. 3;

Pardee, 1918, p. 15) occupies much of the upper reach of the creek's drainage basin.

2.9 $1.8 \quad$ Sanpoil Campground. Former site of Keller lies offshore, beneath Roosevelt Lake.

$3.9 \quad 1.0 \quad$ Large landslide on east shore involves sand, silt, and clay of glacial Lake Columbia and a disconformable terrace-forming cap of deglacial-outwash gravel. Cut on west side of highway exposes rhyodacite lava flow of Eocene age.

$4.8 \quad 0.9 \quad$ Roadcuts expose porphyritic biotite granodiorite (Cretaceous?) and light gray dikes of hypabyssal porphyry (Eocene).

$5.0 \quad 0.2 \quad$ New Manila Creek Road. Continue straight on highway 21.

$5.9 \quad 0.9$ Loading point for timber floated to Lincoln, Washington.

$6.3 \quad 0.4 \quad$ Pull left onto bulldozed gravel east of road. Walk approximately $0.2 \mathrm{mi}$ SSE to scarp of lakeshore landslide.

STOP SA-1: FRENCH JOHNS LOCALITY.

The main part of this scarp exposes 14 flood beds (F-4 through F-14, fig. 4 ) each bracketed by relatively undisturbed sets of varves (V-1 through V-15, fig. 4). Similar rhythmicity characterizes deposits of Lake Columbia $25 \mathrm{~km}$ west at Grand Coulee Dam (fig. 2; Flint and Irwin, 1939, p. 666, pl. 1) and 25 $\mathrm{km}$ east at Ninemile Flat (fig. 1; Jones and others, 1961, p. 20). McKenzie (1980) first reported it from the Sanpoil River valley.

Note the exceptional thinness of $F-10$ and the exceptional thinness and grayness of $\mathrm{F}-11, \mathrm{~F}-12$, and $\mathrm{F}-13$. Also note marker varves in $\mathrm{V}-11$ and $\mathrm{V}-12$ (table 2, fig. 4); we will see these same varves at our next two stops (Ranger Station and Henry Kuehne localities).

MILEAGE

OBSERVATIONS

Cumul. Between

$6.3 \quad 0.0$

Turn back onto highway 21 , headed north (toward Keller).

12.6

6.3

Keller. 
Cumul. Between

13.0 0.4 Silver Creek Road. Turn right (east) and cross Sanpoil River.

13.1 0.1 Turn left onto dirt road ending at Sanpoil River. Park near dead end. Walk upstream to nearby stream cut.

STOP SA-2: RANGER STATION LOCALITY.

Flood beds F-10 and F-11 (fig. 4) display north-dipping foresets both here and at the old Keller locality; currents ran upvalley, toward the Sanpoil sublobe of the Cordilleran ice sheet (fig. 2). I argue in the synopsis that $\mathrm{F}-11, \mathrm{~F}-12$, and $\mathrm{F}-13$ accumulated during the local Fraser maximum. If this is correct then the Sanpoil sublobe may have been as little as $3 \mathrm{~km}$ north of the Ranger Station locality during deposition of these flood beds (figs. 2,3 ).

MILEAGE

OBSERVATIONS

Cumu1. Between

\begin{tabular}{|c|c|c|}
\hline $13 \cdot 3$ & 0.2 & Return to Silver Creek Road, turn left (southeast). \\
\hline 16.2 & 2.9 & $\begin{array}{l}\text { Landslide scarp constituting "Old Keller" locality (figs. } \\
2,4 \text { ) visible across lake at } 3: 00 \text {. Roadcut at left } \\
\text { exposes primary folds in flow-banded Eocene lava flow. }\end{array}$ \\
\hline 16.5 & 0.3 & $\begin{array}{l}\text { Greenish gray rhyodacite dike about } 3 \mathrm{~m} \text { wide cuts lava } \\
\text { flow of mile } 16.2 \text {. }\end{array}$ \\
\hline 16.6 & 0.1 & Turn right onto Kuehne Road. \\
\hline 18.0 & 1.4 & Bear right at fork $0.1 \mathrm{mi}$ beyond cemetery. \\
\hline 18.2 & 0.2 & John Tom Creek. Stay on main road. \\
\hline 18.5 & 0.3 & Landslide scarp on terrace surface at 1:00. \\
\hline 19.6 & 1.1 & Fork at cattle guard. Bear right. \\
\hline $20 \cdot 3$ & 0.7 & $\begin{array}{l}\text { About } 50 \text { m north of another cattle guard, roadcut exposes } \\
\text { Eocene rhyodacite dike (light) cutting Ordovician } \\
\text { metasedimentary rocks (dark, iron-stained; Snook and } \\
\text { others, 1981) that belong to the easternmost of the } \\
\text { eugeosynclinal terranes accreted to the craton in this } \\
\text { part of Washington state (Fox and others, 1977). }\end{array}$ \\
\hline $21 \cdot 3$ & 1.0 & Bear right at fork. \\
\hline 1.5 & $1.2-1.4$ & $\begin{array}{l}\text { Road cuts expose silt that caps cobbly gravel of } \\
\text { deglacial terraces near } 430 \mathrm{~m} \text { ( fig. } 3 \text { ). }\end{array}$ \\
\hline
\end{tabular}


Cumul. Between

21.7-22.1 0.0-0.4 Sandy and gravelly flood beds.

22.2 0.1 Kuehne ranch. Park. Walk about $0.3 \mathrm{mi}$ WSW to top of landslide scarp overlooking lake. Bring lunch.

STOP SA-3: HENRY KUEHNE LOCALITY

The landslide scarp, formed 1982 during springtime lowering of Roosevelt Lake, displays striking up-section decrease in the thickness and disruptiveness of flood beds (fig. 4). Notable flood beds include F-3, which like channel-filling beds higher in the section (fig. 4) comprises many unlaminated, normally graded beds of sand ( $\mathrm{fig} .7$ ); and F-6, which so loaded the underlying varves (V-6) that the varves were both injected into and extruded through the lower half of F-6. The silty tops of most flood beds below F-9 contain many interbeds of unlaminated but normally graded sand. Sparse ripples atop these beds record currents directed more nearly westward (across-valley) than currents responsible for other parts of the flood beds (fig. 2). Many of the unlaminated beds resemble Lowe's (1982, p. 286, 291, 292) examples of deposits of sandy high-density turbidity currents. A cause for such currents at the Henry Kuehne locality might have been remobilization of freshly deposited flood-bed sand on a higher part of the lake bottom to the east.

MILEAGE

OBSERVATIONS

Cumul. Between

$22.2 \quad 0.0 \quad$ Leave Kuehne Ranch and return to Keller.

32.2 $10.0 \quad$ State highway 21. Turn left (south).

$32.6 \quad 0.4 \quad$ Keller. Continue south.

37.7 $5.1 \quad$ New Manila Creek Road. Stay on highway 21 but slow down.

$38.1 \quad 0.4 \quad$ Turn right onto Old Manila Creek Road.

39.2 $\quad 1.1 \quad$ Pull left onto flat opposite large roadcut. Park.

STOP SA-4: LOWER MANILA CREEK LOCALITY.

The roadcut (=MA, fig. 2) exposes about 24 beds each attributable to a Lake Missoula flood. At least six additional Missoula-flood beds appear in landslide scarps below the road, and another 3-6 are likely to be covered by the road itself. Still other Missoula-flood beds exposed at and near Stop SA5 bring the total to 40-45. The base of the section is not exposed.

MILEAGE

OBSERVATIONS

$39.8 \quad 0.6$

Continue up Old Manila Creek Road for $0.6 \mathrm{mi}$. , then park on side of road. 
STOP SA-5: UPPER MANILA CREEK LOCALITY.

The roadcut here, located $15 \mathrm{~m}$ topographically above the top of the SA-4 roadcut and only $20 \mathrm{~m}$ below the top of Lake Columbia's section (515-m lacustrine terrace, fig. 3), probably displays the youngest glaciolacustrine deposits that we have yet seen today. The number of varves between Missoulaflood beds in this cut appears to range from 15-20, about half as many as seen lower in the section (table 1). Bottom sediments of Lake Missoula near Ninemile Creek (fig. 1) show a parallel trend (fig. 8) which Waitt (1980, p. 674-675) ascribes to deglacial thinning of Lake Missoula's ice dam. The roadcut also displays exceptionally thick $(1-3 \mathrm{~cm})$ silt layers in many of the varves. Conceivably these silt layers record small jokulhlaups into Lake Columbia from the Sanpoil or Columbia drainage.

MILEAGE OBSERVATION

Cumul. Between

40.3 $0.5 \quad$ Turn sharp right onto New Manila Creek Road.

40.5 0.2 Turn left onto unpaved road to Mt. Tolman.

40.7 $\quad 0.2 \quad$ Bear left at fork, then park on right side of road.

STOP SA-6: LAST CHANCE CREEK LOCALITY.

Stream banks about $0.1 \mathrm{~m}$ NNW of 40.7-mile fork expose colluvium and (or) fan alluvium conformably overlying the apparent top of Lake Columbia's section at an elevation of $510 \mathrm{~m}$. Note extreme thinness of flood beds separated by few varves.

MILEAGE OBSERVATION

Cumul. Between

40.9 0.2 Turn left (east) on new Manila Creek Road.

$42.5 \quad 1.6 \quad$ Roadcuts expose eolian sand overlying fluvial or deltaic gravel of the Sanpoil(?) River. The gravel, at an elevation of $520 \mathrm{~m}$, may have closed off the mouth of the Manila Creek arm of Lake Columbia near the end of the last glaciation.

43.2 $0.7 \quad$ Turn right (south) onto highway 21.

48.2 5.0 Begin short $(0.1 \mathrm{mi})$ descent to Columbia River. Take Keller Ferry to National Park Service campground on south shore of Roosevelt Lake. Those unable to fit on first ferry can either wait near the slip or go straight at mile 48.2 onto a low terrace. A lakeside cut into this terrace exposes a flood bed whose basal foresets imply currents directed westward, toward the Grand Coulee (Ferry Slip locality, figs. 2, 4).

END OF DAY 1. 
Table 1. Ranges of varve counts from Fraser-age deposits of the Sanpoil arm. Range for a given bed at a given locality obtained by making two counts, one treating as simple varves nearly all silt-and-clay couplets thicker than 5 $\mathrm{mm}$, the other lumping selected sets of non-rhythmic couplets into composite varves. Italicized number denotes count made incomplete by erosion at contact with overlying flood bed; all other counts presumably complete. Beds not counted: i., exposed but mostly inaccessible; e., mostly eroded; c., covered.

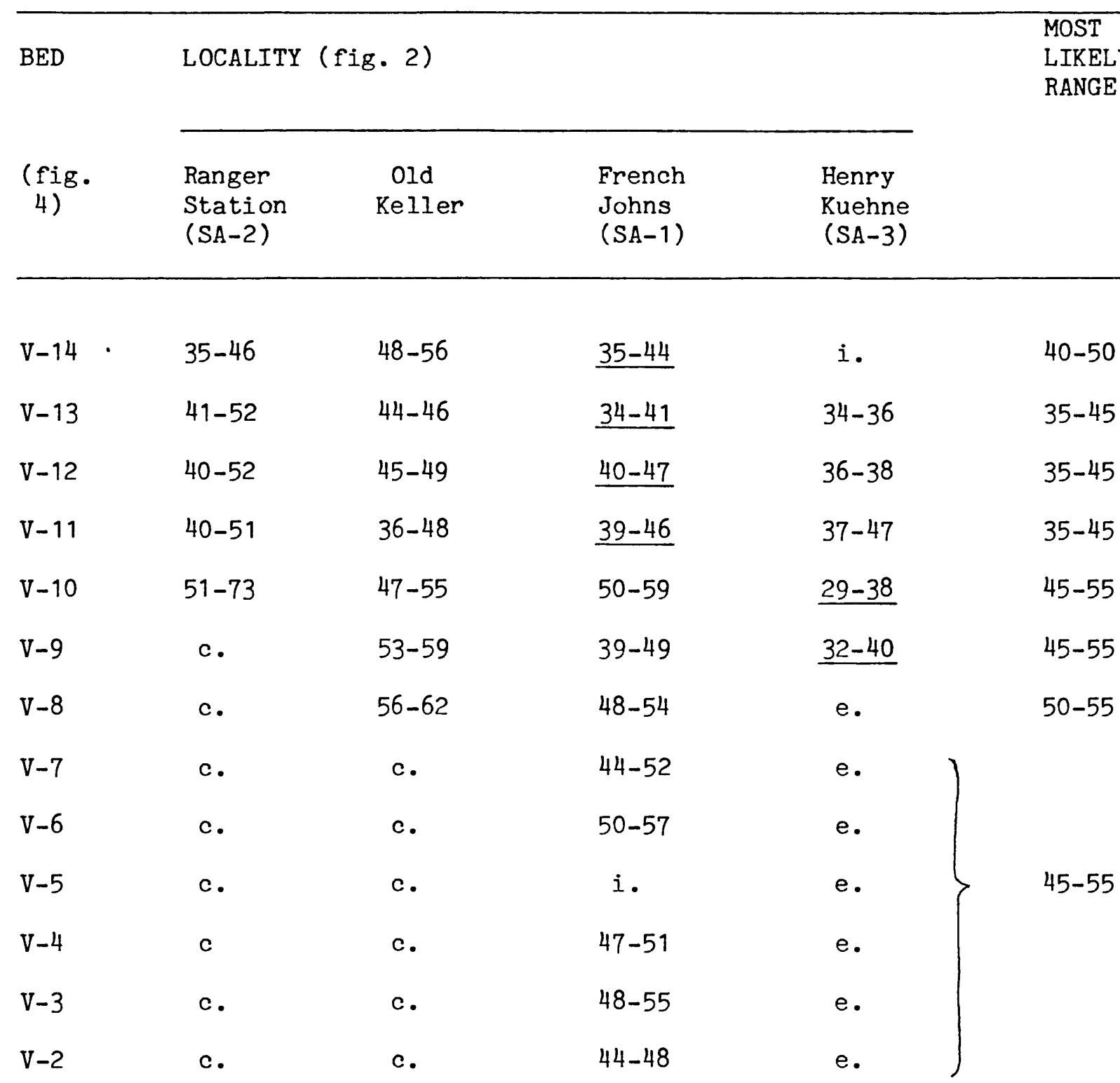


Table 2. Varves that can be correlated between two or more of the following localities: Ranger Station (RS; stop SA-2), Old Keller (OK), French Johns (FJ; stop SA-1) and Henry Kuehne (HK; stop SA-3).

\section{VARVED VARVE}

BED

$\begin{array}{lll}\text { Distinctive } & \text { Stratigraphic position, as } & \text { Lateral variation } \\ \text { lithologic } & \text { number (a, approximate } & \text { (if any) and known } \\ \text { feature } & \text { number) of varves from } & \text { distribution }\end{array}$

top ( $t$ ) or bottom (b) of bed

V-13 Thick base of
very fine sand

$\mathrm{V}-12$

Thick base of
very fine sand

Thick base of

very fine sand

V-11 Thick base of
of very
fine sand

Massive coarse silt and very fine sand with tabular clasts of varves

V-10 Thick base of very fine sand

Exceptionally thick

$(10 \mathrm{~cm})$ clayey part of varve

Exceptionally thick $(5-7 \mathrm{~cm})$ clayey part of varve $V-8$ Silt, $10 \mathrm{~cm}$ thick

$5(t)$

$8(t)$

$15(t, a)$

$3(t)$

$12(t, a)$

$1(t)$, of which the marker forms the base

$11(t)$

$7(b, a)$

$11(t, a)$ at $\mathrm{OK}$
Not distinctive at $\mathrm{OK}$ and $\mathrm{RS}$ abundance of sandy varves at these localities

Thins from $2-3 \mathrm{~cm}$ at $\mathrm{RS}$ to $0.8 \mathrm{~cm}$ at $\mathrm{HK}$

Not distinctive at $\mathrm{OK}$ owing to abundance of sandy varves at this locality

Thins from $8 \mathrm{~cm}$ at $\mathrm{RS}$ to $0.2-0.5$ $\mathrm{cm}$ at $\mathrm{HK}$; overlying varves eroded at FJ and partly detached at $\mathrm{HK}$

Recognized only at RS and $\mathrm{OK}$

Recognized only at RS OK

Recognized only at RS and $\mathrm{OK}$

Recognized only at RS and $\mathrm{OK}$

Recognized only at $\mathrm{OK}$ and FJ: covered, if present at all, at RS; cut out by erosion HK. At FJ 3-5 of the overlying varves have probably been removed by erosion.

Recognized only at $\mathrm{FJ}$ and $\mathrm{HK}$ : covered, if present at all, at $\mathrm{RS}$ and $\mathrm{OK}$ 
Table 3. Location of principal stratigraphic sections.

\begin{tabular}{|c|c|}
\hline $\begin{array}{l}\text { NAME } \\
(\text { fig. 2) }\end{array}$ & LOCATION \\
\hline $\begin{array}{l}\text { Ranger } \\
\text { Station }\end{array}$ & $\begin{array}{l}\text { Natural stream bank } 0.64 \mathrm{~km} \mathrm{~N}, 0.21 \mathrm{~km} \mathrm{E} \text { of } \mathrm{SW} \text { corner sec. 20, } \\
\text { T. } 30 \mathrm{~N}, \mathrm{R} .33 \mathrm{E} \text { (stop SA-2) }\end{array}$ \\
\hline $\begin{array}{r}\text { Meadow } \\
\text { Creek }\end{array}$ & $\begin{array}{l}\text { Landslide scarp } 0.19 \mathrm{~km} \mathrm{~S}, 0.05 \mathrm{~km} \mathrm{E} \text { of } \mathrm{NW} \text { corner sec. 33, } \\
\text { T.30N, R.33E }\end{array}$ \\
\hline $\begin{array}{l}\text { Old } \\
\text { Keller }\end{array}$ & $\begin{array}{l}\text { Landslide scarp } 0.40 \mathrm{~km} \mathrm{~N}, 0.48 \mathrm{~km} \mathrm{E} \text { of SW corner sec. } 33 \text {, } \\
\text { T.30N, R. } 33 \mathrm{E}\end{array}$ \\
\hline $\begin{array}{r}\text { John } \\
\text { Tom }\end{array}$ & $\begin{array}{l}\text { Western face of landslide block approx. } 0.6 \mathrm{~km} \mathrm{~N}, 0.5 \mathrm{~km} \mathrm{E} \text { of SW } \\
\text { corner sec. } 9, \mathrm{~T} .29 \mathrm{~N}, \mathrm{R} .33 \mathrm{E}\end{array}$ \\
\hline $\begin{array}{r}\text { Manila } \\
\text { Creek }\end{array}$ & $\begin{array}{l}\text { Road cuts along old Manila Creek Rd. approx. } 0.25 \mathrm{~km} \mathrm{~N}, 0.5-0.7 \\
\mathrm{~km} \text { E of SW corner sec. 18, T.29N, R. 33E (stop SA-4) }\end{array}$ \\
\hline $\begin{array}{r}\text { French } \\
\text { Johns }\end{array}$ & $\begin{array}{l}\text { Landslide scarp } 0.16 \mathrm{~km} \mathrm{~N}, 0.40 \mathrm{~km} \mathrm{E} \text { of SW corner sec. } \\
20 \text {, T.29N, R. } 33 \mathrm{E} \text { (stop SA-1) }\end{array}$ \\
\hline $\begin{array}{l}\text { Sage } \\
\text { Trig }\end{array}$ & $\begin{array}{l}\text { Landslide scarp } 0.32 \mathrm{~km} \mathrm{~N}, 0.05 \mathrm{~km} \mathrm{E} \text { of SW corner sec. 29, } \\
\text { T.29N, R.33E }\end{array}$ \\
\hline $\begin{array}{l}\text { Henry } \\
\text { Kuehne }\end{array}$ & $\begin{array}{l}\text { Landslide scarp } 0.26 \mathrm{~km} \mathrm{S,} 0.76 \mathrm{~km} \text { W of } \mathrm{NE} \text { corner } \\
\text { sec. } 32, \mathrm{~T} .29 \mathrm{~N}, \mathrm{R} .33 \mathrm{E} \text { (stop SA-3) }\end{array}$ \\
\hline $\begin{array}{r}\text { Ferry } \\
\text { Slip }\end{array}$ & $\begin{array}{l}\text { Landslide scarp } 0.13 \mathrm{~km} \mathrm{S,} 0.64 \mathrm{~km} \mathrm{~W} \text { of NE corner sec. } 8, T .28 \mathrm{~N} \text {, } \\
\text { R. } 33 \mathrm{E}\end{array}$ \\
\hline
\end{tabular}




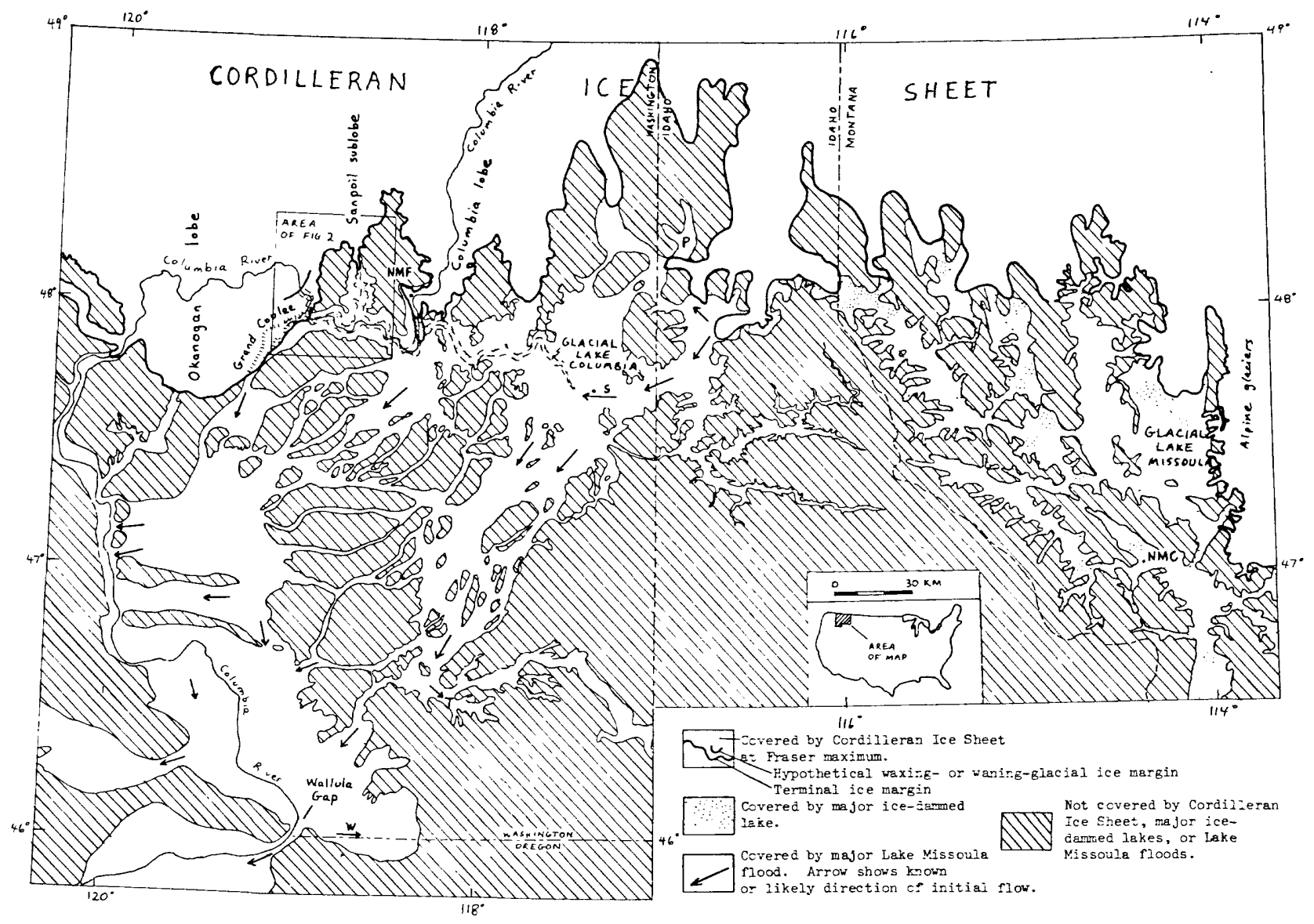

Figure 1. Southern part of the Cordilleran ice sheet and adjacent areas during the Fraser glaciation. Modified from Richmond and others (1965), Baker (1973, pl. 1), Waitt (1980, p. 655), and Waitt and Thorson (1983). Glacial Lake Columbia at 515-m level. NMC, Ninemile Creek; NMF, Ninemile Flat; P, Priest River valley; SP, Spokane; T, Tucannon River; W, Walla Walla River. 


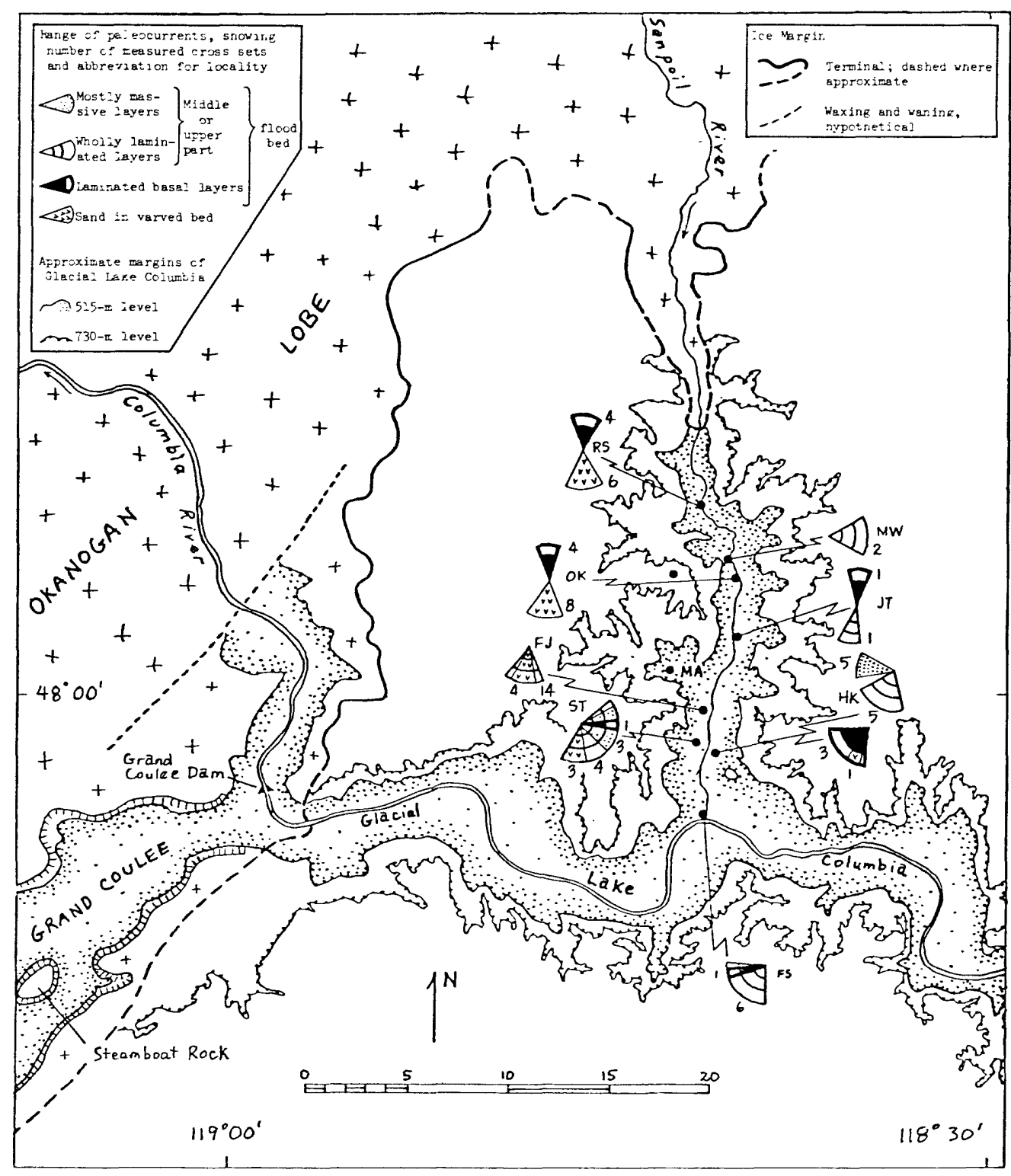

Figure 2. Fraser-age ice margins, shorelines, and paleocurrents in the vicinity of the lower Sanpoil River valley. Terminal ice margin from Flint and Irwin (1939, p. 664), Hibbert (1980, p. 14), Atwater and McGroder (1982), and figure 3 of this report. Lake having shoreline at $730 \mathrm{~m}$ requires a barrier either of ice (as shown on the map) or of rock at the site of the Grand Coulee. Lake having 515-m shoreline, in contrast, probably discharged through the Grand Coulee and probably had an ice dam some distance west of the Grand Coulee, such as the hypothetical waxing- or waning-glacial ice margin on the map. Hachured lines denote present walls of the Grand Coulee. Historic courses of principal rivers approximate the pre-Fraser drainage. RS, Ranger Station (stop SA-2); MW, Meadow Creek; MT, Mt. Tolman; OK, OId Keller; JT, John Tom Creek; MA, Manila Creek (stop SA4; SA-5 and SA-6 located about $1 \mathrm{~km}$ west and northwest, respectively, of $\overline{M A}$; FJ, French Johns (stop SA-1); ST, Sage Trig; HK, Henry Kuehne (stop SA3); FS, Ferry Slip (table 3). 


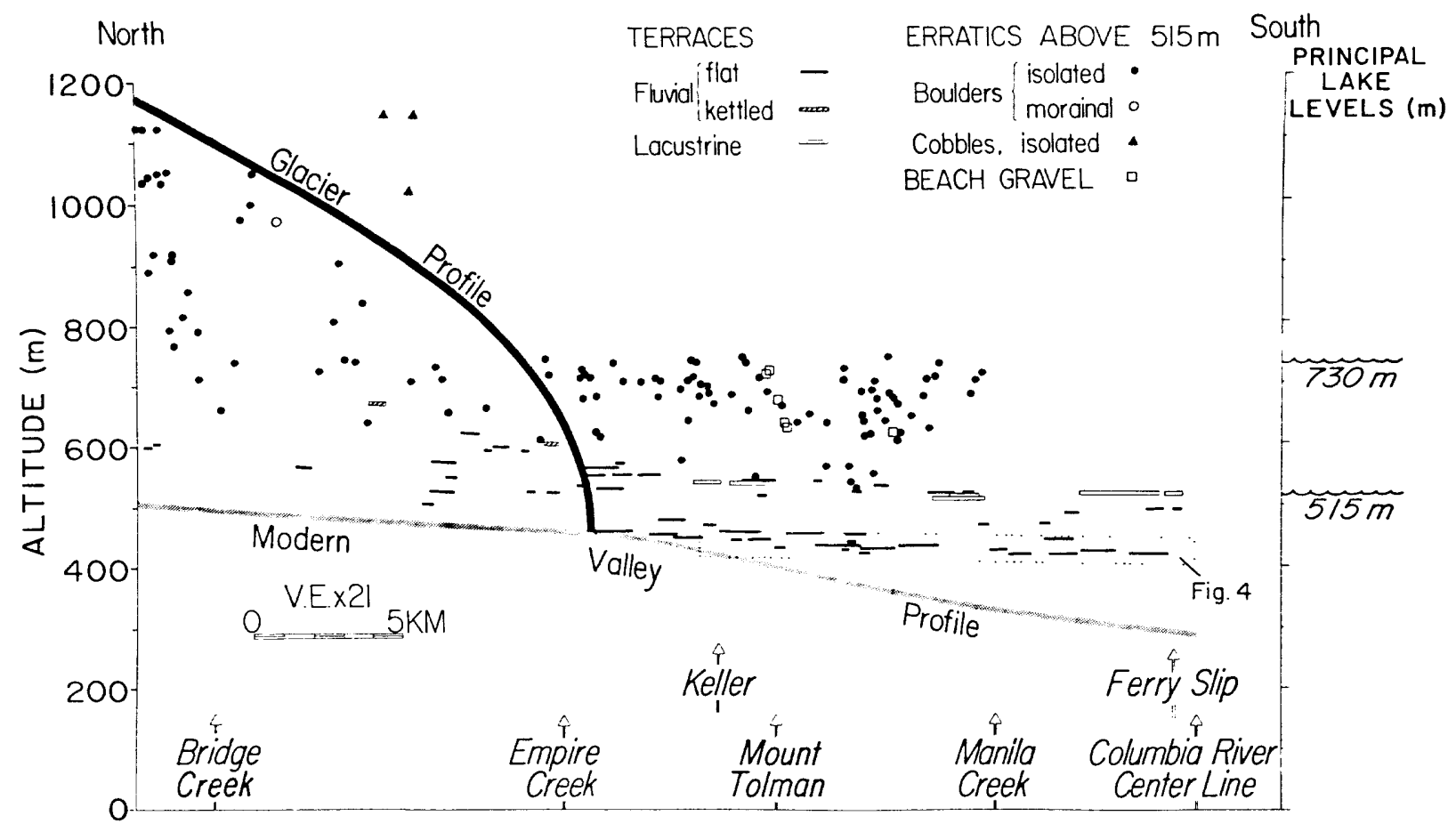

Figure 3. Glacial, lacustrine, and fluvial features projected onto a longitudinal profile of the lower Sanpoil River valley. Glacier profile, showing appendage of Okanogan lobe at maximum Fraser-age extent, represents best fit of a theoretical valley-glacier profile to the distribution of erratic boulders above $750 \mathrm{~m}$ and to the down-valley limit of kame terraces. This fit, made by J. C. Yount with the procedures of Schilling and Hollin (1981), employs a shape factor of 0.6 (at 0.5 the ice is treated as a semicylinder, at 1.0 an infinite sheet) and an average basal shear stress of 0.8 bar (at 1 bar ice flows rapidly). Location of erratics north of Manila Creek from mapping by Cochran and Warlow (1980) and B. F. Atwater and M. F. McGroder (unpub., 1980-1981); erratics south of Manila Creek have yet to be mapped. Cochran and Warlow (1980) also mapped the beach gravel near Meadow Creek and distinguished between lacustrine and fluvial terraces north of Manila Creek. Base level for the modern valley, which is now drowned behind Grand Coulee Dam, is taken as the 300-m altitude of the mouth of the Sanpoil River recorded by Flint (1936, pl.6). 


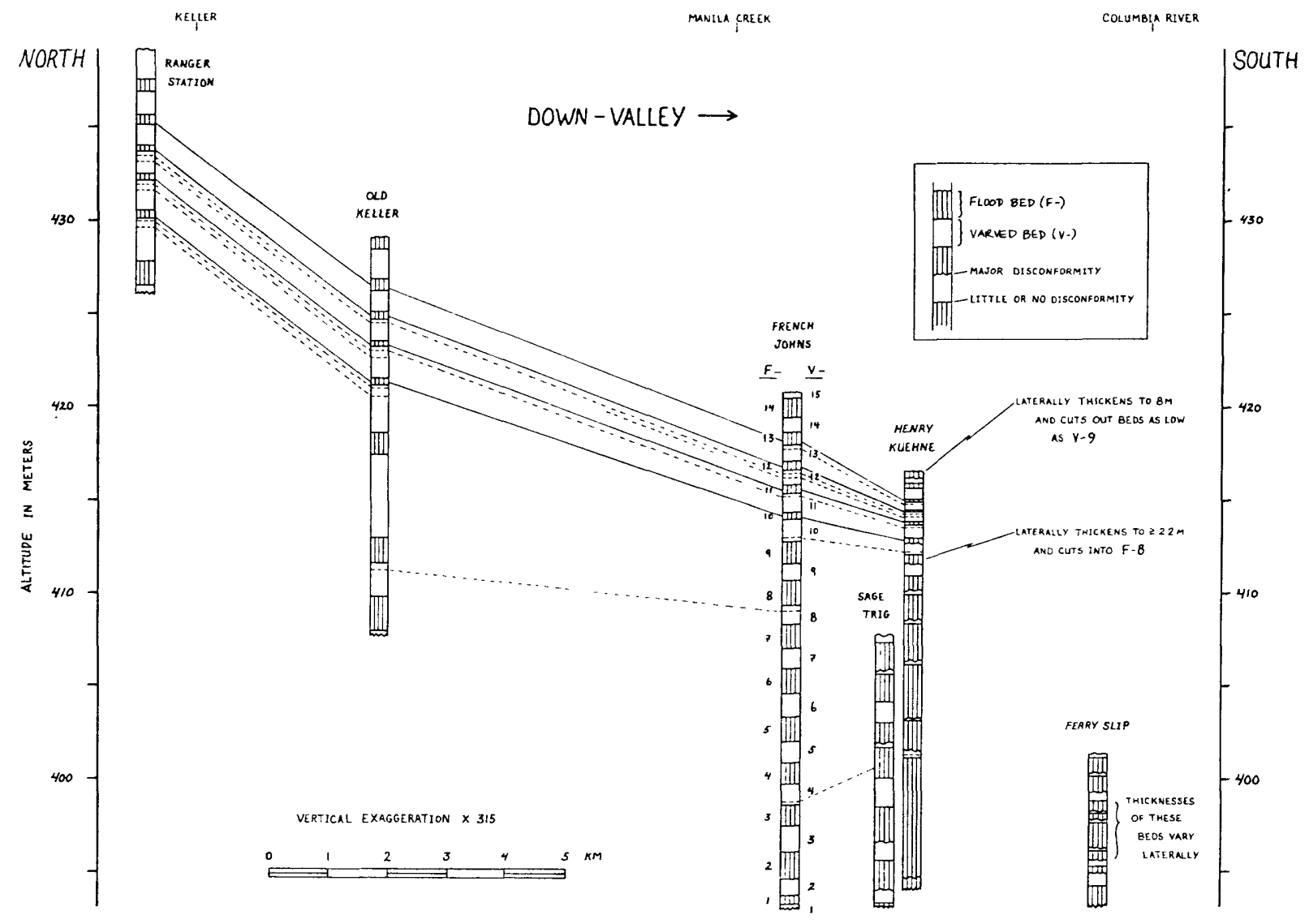

Figure 4. Skeletal columnar sections of Fraser-age deposits of the Sanpoil arm of glacial Lake Columbia. Geomorphic setting shown in figure 3 . Dashed lines between varved beds connect principal marker layers common to more than one locality (table 2). Solid lines connect the only three consistently gray-topped flood beds (F-11, F-12, and F-13) at these localities and the thin but brown-topped flood bed $(F-10)$ that underlies them. Dotted and solid lines both produce the same overall correlation; hence the alphanumeric labels for the French Johns locality (stop SA-1) can be applied as well to the Ranger Station (stop SA-2), Old Keller, and Henry Kuehne (stop SA-3) localities. 


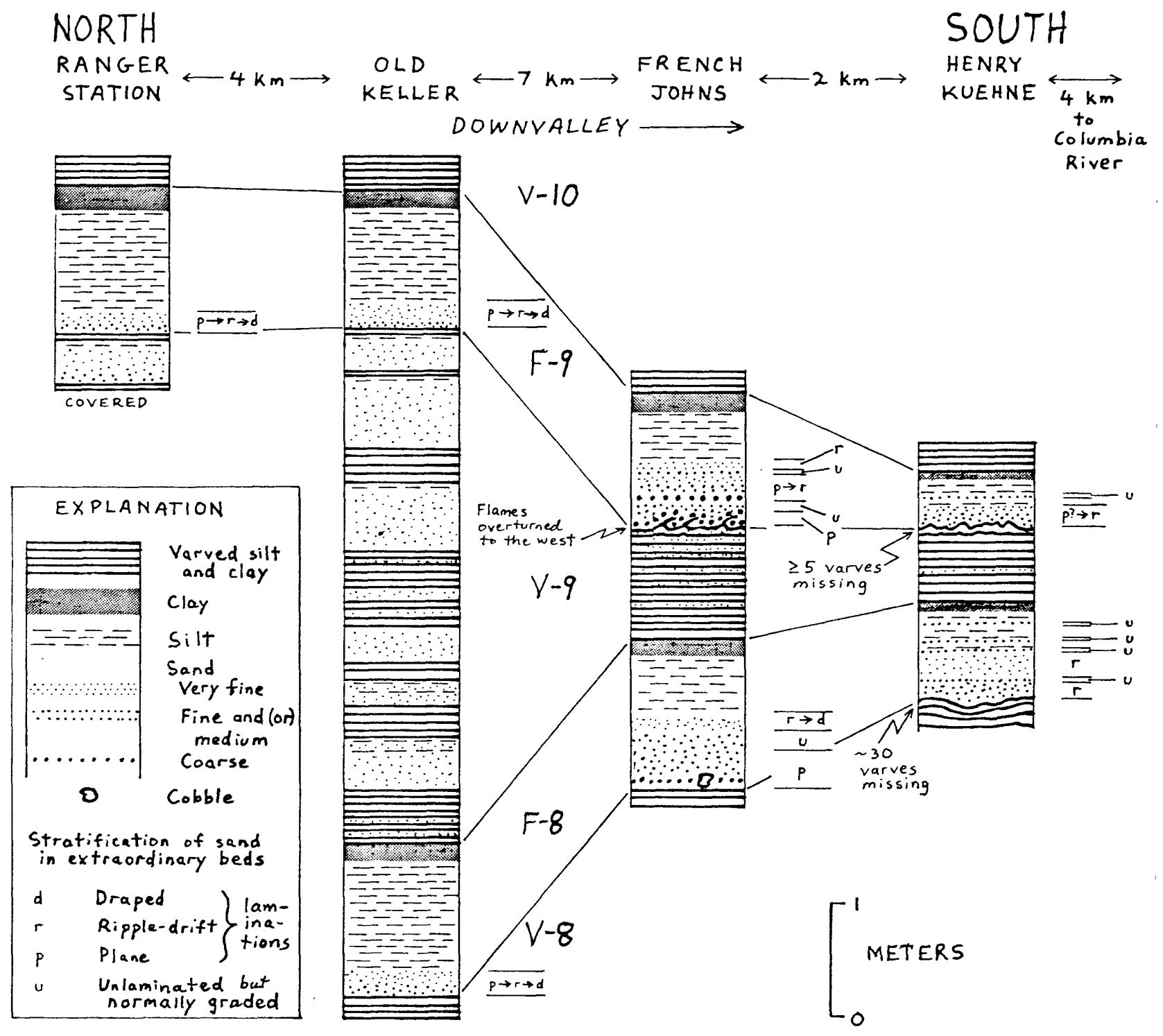

Figure 5. Changes in flood beds F-8 and F-9 and varved bed V-9 along the axis of the Sanpoil River valley. At Henry Kuehne locality bed F-9 locally thickens to at least $2.2 \mathrm{~m}$, with virtually all of the additional thickness taken up by sand. For a more detailed sketch of F-8 at old Keller locality see fig. 6 . 


\section{SEDIMENTARY MEAN ANALOGOUS STRUCTURE GRAIN SIZE BOUMA (1962)}
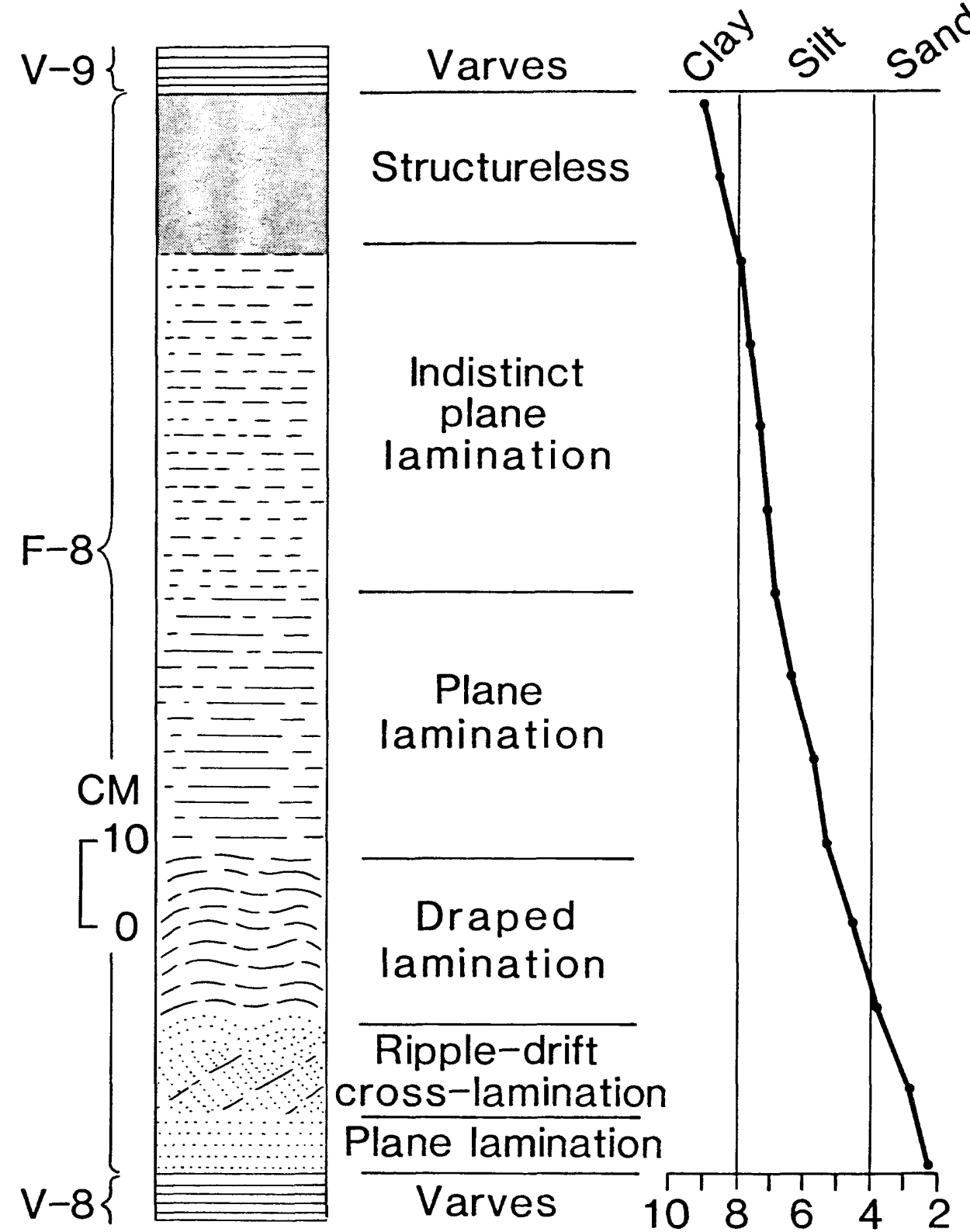

Pelagic

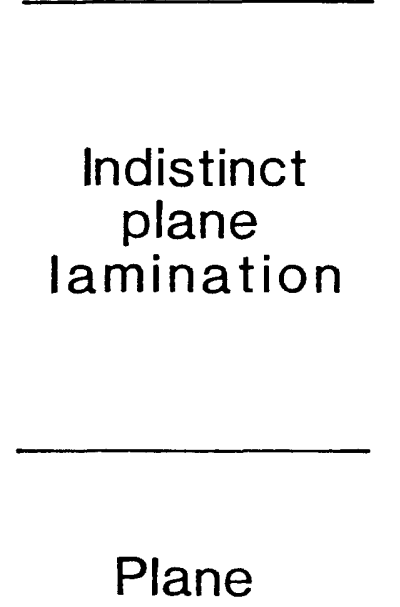
lamination

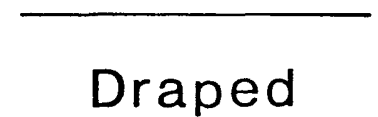
lamination

\section{Ripple-drift} cross-lamination Plane lamination Varves 10

\section{(Phi units)}

Figure 6. Upward progression of grain size (by sieving and electro-resistance analysis) and sedimentary structures in flood bed F-8, old Keller locality. Analogy with marine turbidites refers to intervals of Bouma (1962, p. 49). 


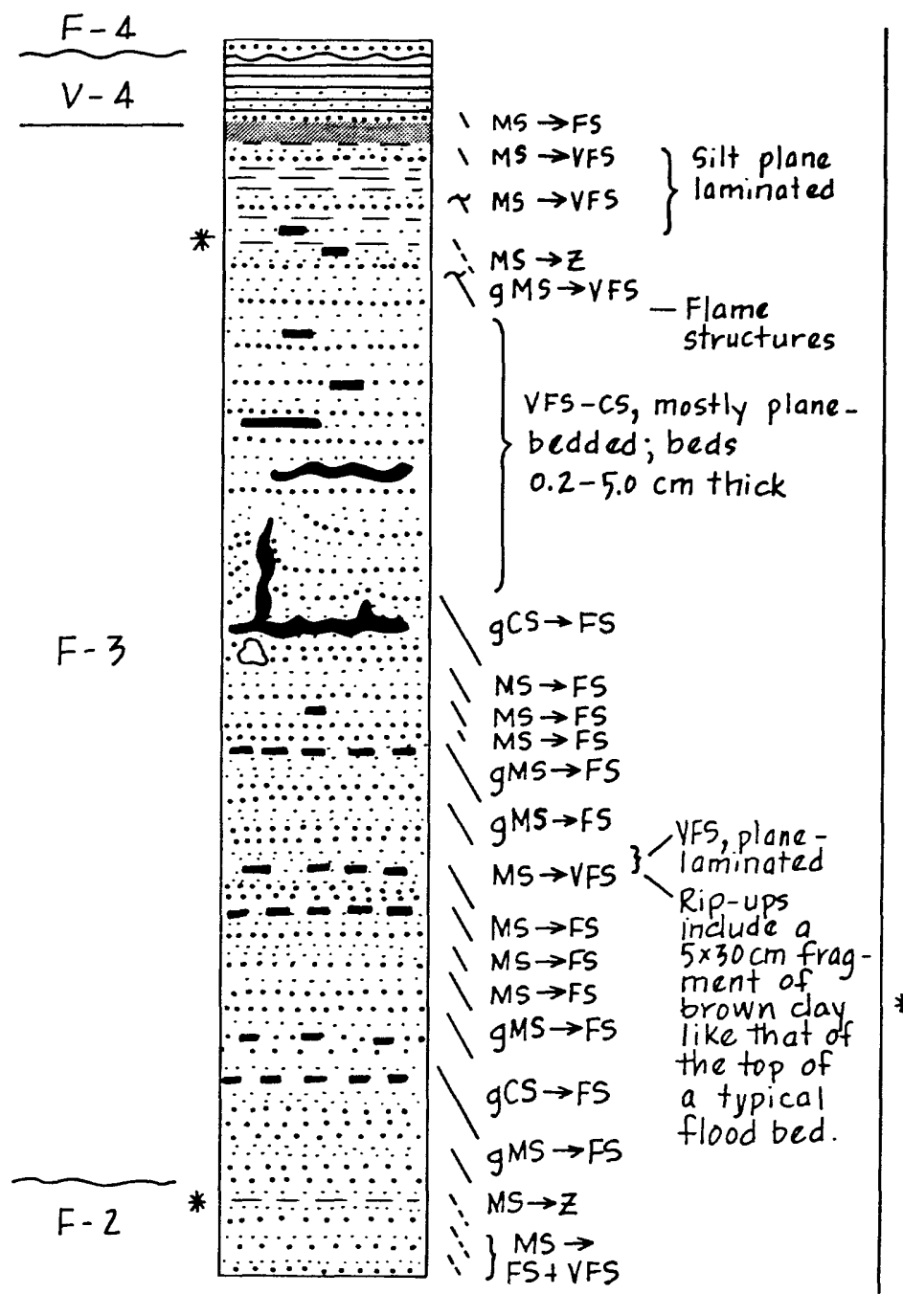

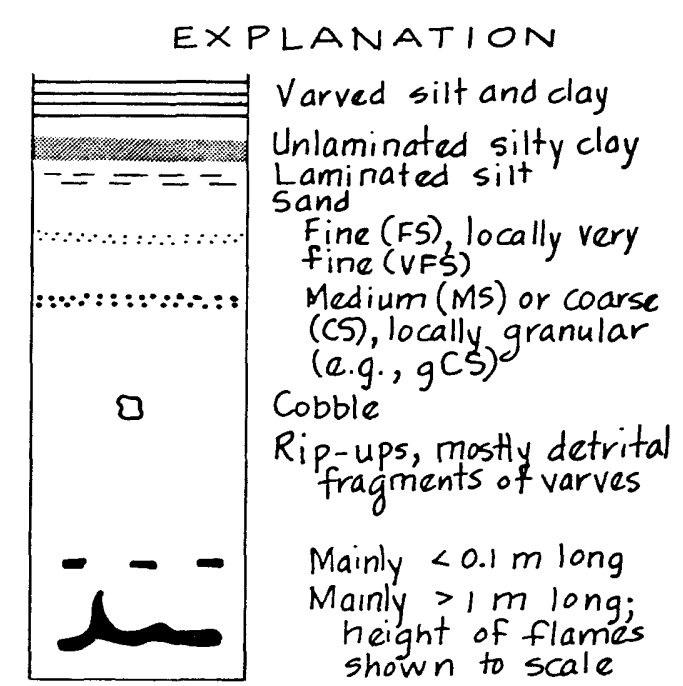

Normally graded beds:

Unlaminated or mostly so; crossed

with sigmoidal line where ripple-arift cross-laminated at top

$\because \quad$ Indistinctly plane-laminated with
some alternation of grain size

* Comparable stratigraphic positions within beds F-2 and F-3

$$
\left[\begin{array}{l}
1.0 \\
\text { METERS } \\
0
\end{array}\right.
$$

Figure 7. Repeated upward fining of mostly unlaminated sand in flood bed F-3, Henry Kuehne locality (stop SA-3). This kind of graded bedding also characterizes the thickest, channel-filling parts of F-8 and F-9 at this locality (fig. 4). 


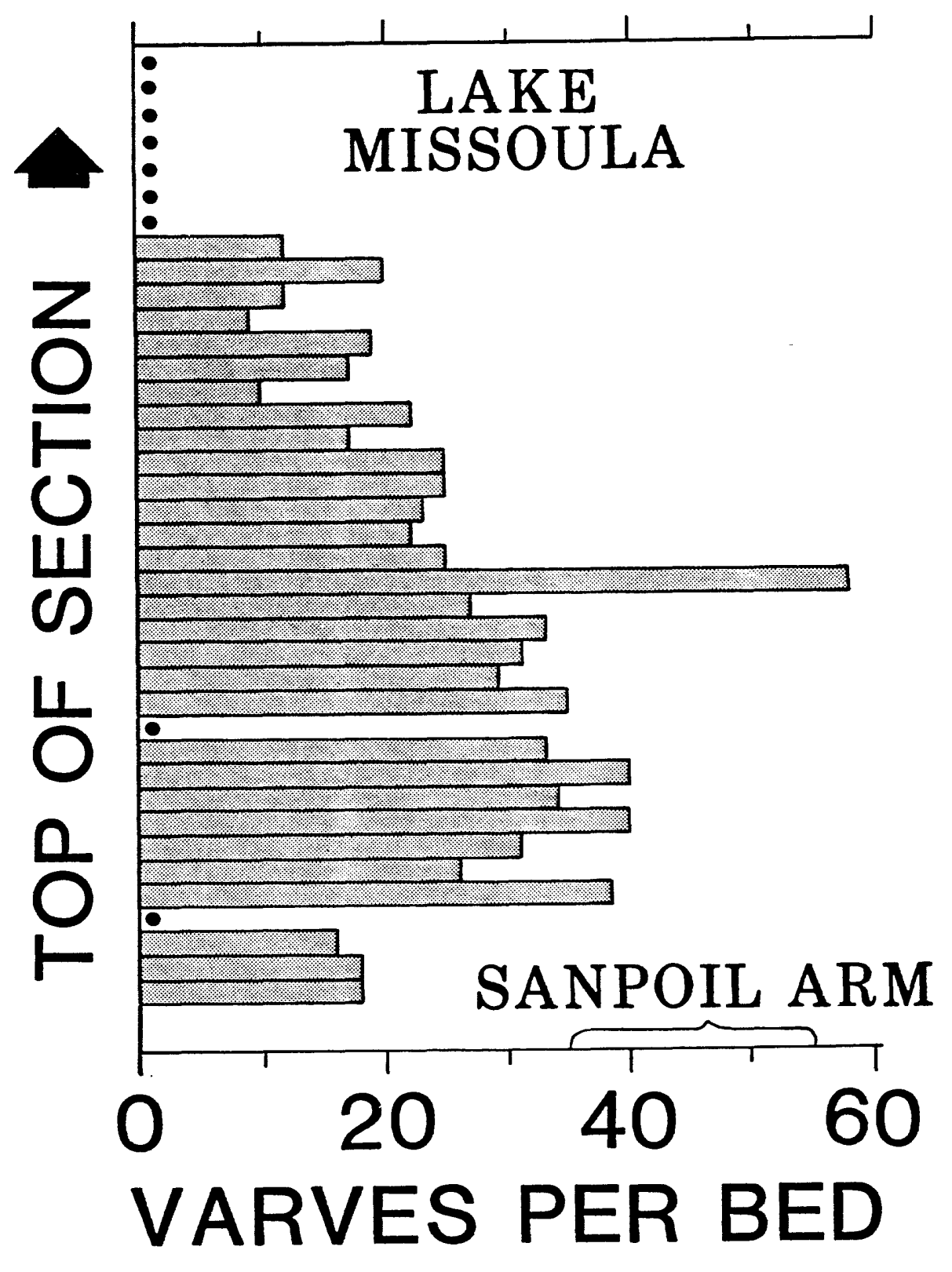

- TOO WEATHERED TO COUNT

Figure 8. Comparison of varve counts from bottom sediment of glacial Lake Missoula (Chambers, 1971, App. III) with the aggregate range of the most likely number of varves in varved beds of glacial Lake Columbia (table 1). 


\section{PATH OF FLOODS FROM LAKE MISSOULA}

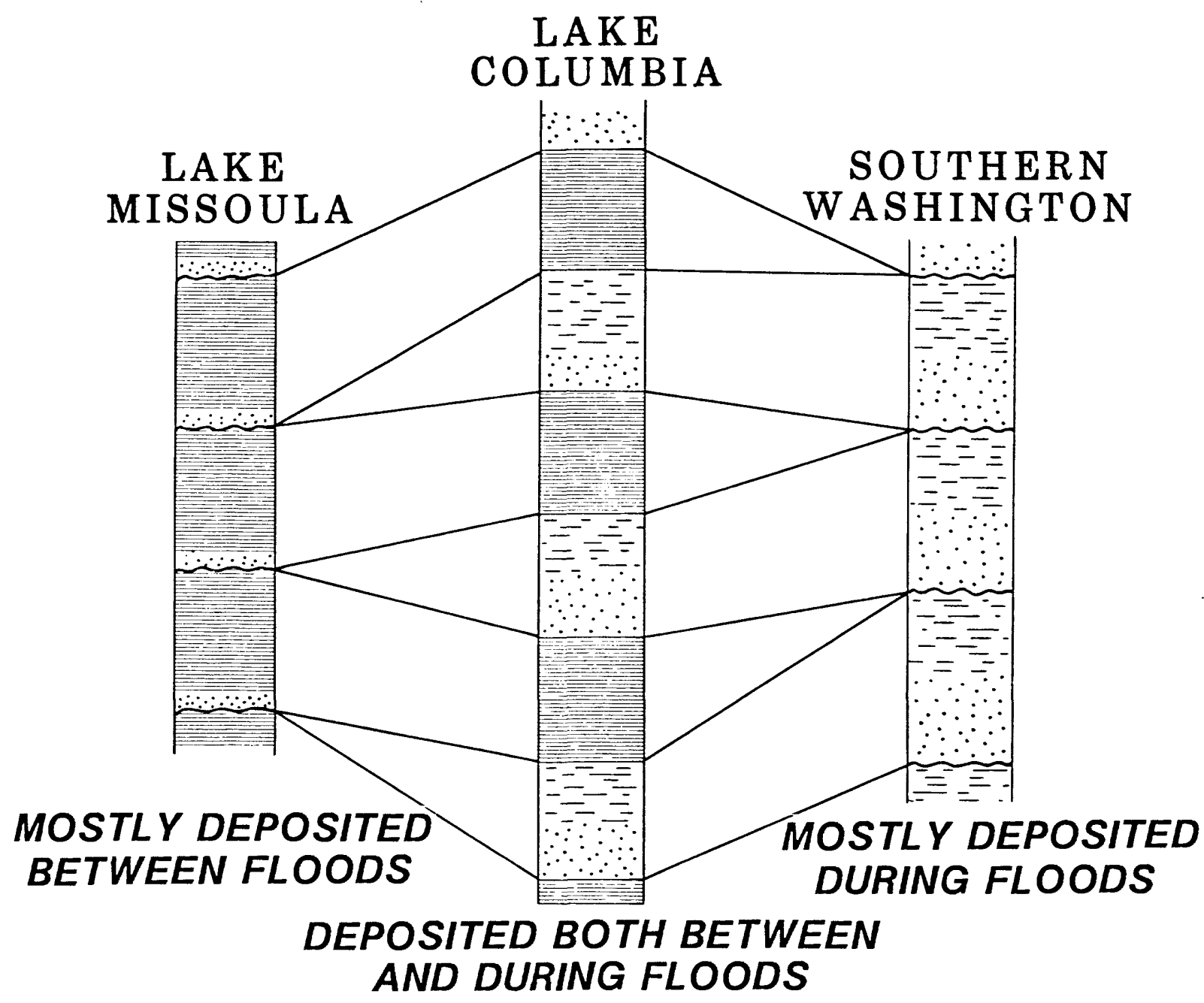

Figure 9. Likely time-stratigraphic correlation of the varved and flood beds of glacial Lake Columbia with bottom sediments of glacial Lake Missoula and backflood deposits in southern Washington. 


\section{REFERENCES CITED}

Atwater, B. F., and McGroder, M. F., 1982, Preliminary geologic map of the Keller quadrangle, Ferry County, Washington: unpubl. U. S. Geological Survey report to Colville Confederate Tribes, Nespelem, Wash., scale $1: 62,000$.

Baker, V. R., 1973, Paleohydrology and sedimentology of Lake Missoula flooding in eastern Washington: Geological Society of America Special Paper 144, 79 p.

Bouma, A. H., 1962, Sedimentology of some Flysch Deposits: New York, Elsevier, $168 \mathrm{p}$.

Bretz, J H., 1923, Glacial drainage on the Columbia Plateau: Geological Society of America Bulletin, v. 34, p. 573-608.

Chambers, R. L., 1971, Sedimentation in Glacial Lake Missoula: unpubl. M.S. thesis, University of Montana, Missoula, $100 \mathrm{p}$.

Cochran, D. S., and Warlow, J. C., 1980, Engineering and environmental geology, Mt. Tolman project, Ferry County, Washington: unpubl. report to Amax Exploration, Inc., and the Colville Confederated Tribes, Nespelem, Wash., 89 p., map scale 1:4800.

Flint, R. F., 1936, Stratified drift and deglaciation in eastern Washington: Geological Society of America Bulletin, v. 47, p. 1849-1884.

Flint, R. F., and Irwin, W. H., 1939, Glacial geology of Grand Coulee Dam, Washington: Geological Society of America Bulletin, v. 50, p. 661-680.

Fox, K. F., Jr., Rinehart, C. D., and Engels, J. C., 1977, Plutonism and orogeny in north-central Washington--timing and regional context: U.S. Geological Survey Professional Paper 989, 27 p.

Hibbert, D. M., 1980, Quaternary geology and the history of the landscape along the Columbia between Chief Joseph and Grand Coulee Dams: unpubl. report, contract DACW 67-78-C-0106, U. S. Corps of Engineers, Seattle, Wash., $30 \mathrm{p}$.

Jones, F. O., Embody, D. R., and Peterson, W. L., 1961, Landslides along the Columbia River valley northeastern Washington: U. S. Geological Survey Professional Paper 367, $98 \mathrm{p}$.

Lowe, D. R., 1982, Sediment gravity flows: II. Depositional models with special reference to the deposits of high-density turbidity currents: Journal of Sedimentary Petrology, v. 52, p. 279-297.

McKenzie, G. D., 1980, Surficial deposits, p. 28-61 in Cochran, D. S., and Warlow, J. C., Engineering and environmental geology, Mt. Tolman project, Ferry County, Washington: unpubl. report to Amax Exploration, Inc., and the Colville Confederated Tribes, Nespelem, Wash. 
Pardee, J. T., 1918, Geology and mineral deposits of the Colville Indian Reservation, Washington: U. S. Geological Survey Bulletin 677, 186 p.

Richmond, G. M., Frizzell, R., Neff, G. E., and Weis, P., 1965, The Cordilleran ice sheet of the northern Rocky Mountains, and related Quaternary history of the Columbia Plateau, in Wright, H. E., Jr., and Frey, D. G., eds., The Quaternary of the United States: Princeton, N. J., Princeton University Press, p. 231-242.

Schilling, D. H., and Hollin, J. T., 1981, Numerical reconstructions of valley glaciers and small ice caps, in Denton, G. H., and Hughes, T. J., eds., The Last Great Ice Sheets: New York, Wiley, p. 207-220.

Snook, J. R., Lucus, H. E., and Abrams, M. J., 1981, A cross section of a Nevada-style thrust in northeast Washington: Washington Division of Geology and Earth Resources, Report of Investigations 25, 9 p.

Waitt, R. B., Jr., 1980, About forty last-glacial Lake Missoula jokulhlaups through southern Washington: Journal of Geology, v. 88, p. 653-679.

Waitt, R. B., Jr., and Thorson, R. M., 1983, The Cordilleran ice sheet in Washington, Idaho, and Montana, in Porter, S. C., ed., Late Pleistocene Environments of the United States: University of Minnesota Press, p. 53-70. 